\title{
Influence of stress factors and socio- demographic characteristics on the sleep quality of nursing students
}

\author{
INFLUÊNCIA DE FATORES DE ESTRESSE E CARACTERÍSTICAS SOCIODEMOGRÁFICAS \\ NA QUALIDADE DO SONO DE ESTUDANTES DE ENFERMAGEM
}

\author{
INFLUENCIA DE LOS FACTORES DE ESTRÉS Y DE LAS CARACTERÍSTICAS \\ SOCIODEMOGRAFICAS EN LA CALIDAD DEL SUEÑO DE ESTUDIANTES DE ENFERMERÍA
}

\section{Sonia Betzabeth Ticona Benavente ${ }^{1}$, Rodrigo Marques da Silva ${ }^{2}$, Aline Baraldi Higashi ${ }^{3}$, Laura de Azevedo Guido ${ }^{4}$, Ana Lucia Siqueira Costa ${ }^{5}$}

\begin{abstract}
Objective: To analyze the influence of stress factors and socio-demographic characteristics on the sleep quality of nursing students. Method: An analytical cross-sectional and quantitative study, conducted with 151 nursing students in São Paulo between March and April of 2012. A form for socio-demographic characteristics, the Instrument to Evaluate Stress in Nursing Students and the Pittsburgh Sleep Index were applied. Results: High levels of stress was predominant for Time Management (27.8\%) and Professional Training (30.5\%) and low sleep quality (78.8\%). The Professional Communication, Professional Training and Theoretical Activity are positively correlated to sleep quality. Work activity, academic year and time for daily studies contributed to a low quality of sleep. Conclusion: Few stress factors from the academic environment and some sociodemographic characteristics contributed to the reduction of sleep quality in students.
\end{abstract}

\section{DESCRIPTORS}

Students, nursing

Stress, psychological

Sleep deprivation

Sleep disorders

Education, nursing

\section{RESUMO}

Objetivo: Analisar a influência dos fatores de estresse e das características sociodemográficas na qualidade do sono de discentes de enfermagem. Método: Estudo analítico, transversal e quantitativo, realizado com 151 discentes de enfermagem de São Paulo entre março e abril de 2012. Aplicaram-se um Formulário para caracterização sociodemográfica, o Instrumento Avaliação de Estresse em Estudantes de Enfermagem e o Índice de Qualidade de Sono de Pittsburgh. Resultados: Verificouse predomínio de muito alto estresse no Gerenciamento do Tempo $(27,8 \%)$ e Formação Profissional $(30,5 \%)$ e de baixa qualidade do sono (78,8\%). A Comunicação Profissional, a Formação Profissional e a Atividade Teórica correlacionaram-se positivamente à qualidade do sono. $A$ atividade de trabalho, o ano acadêmico e o tempo de estudos diários contribuíram para a baixa qualidade do sono. Conclusão: Alguns fatores de estresse do ambiente acadêmico e algumas características sociodemográficas contribuem para a redução da qualidade do sono do estudante.

\section{DESCRITORES}

Estudantes de enfermagem

Estresse psicológico

Privação do sono

Transtornos do sono

Educação em enfermagem

\section{RESUMEN}

Objetivo: Analizar la influencia de los factores de estrés y de las características sociodemográficas en la calidad del sueño de estudiantes de enfermería. Método: Estudio analítico, transversal y cuantitativo, realizado con 151 alumnos de pregrado en enfermería de São Paulo entre marzo y abril del año 2012. Los instrumentos utilizados fueron: un formulario para la caracterización sociodemográfica, el instrumento de Evaluación del Estrés en Estudiantes de Enfermería y el Índice de Calidad del Sueño de Pittsburgh. Resultados: Se verificó predominio de estrés de nivel muy alto en la Gestión del Tiempo $(27,8 \%)$ y en la Formación Profesional (30,5\%), y de baja calidad de Sueño $(78,8 \%)$. La Comunicación Profesional, la Formación Profesional y la Actividad Teórica se correlacionaron positivamente con la calidad del sueño. La actividad laboral, el año académico y el tiempo diario de estudio contribuyeron para la disminución de la calidad del sueño. Conclusión: Algunos factores de estrés del ambiente académico y algunas características sociodemográficas contribuyen a la disminución de la calidad del sueño del estudiante de enfermería.

\section{DESCRIPTORES}

Estudiantes de enfermería

Estrés psicológico

Privación de sueño

Trastornos del sueño

Educación en enfermería

\footnotetext{
${ }_{1}^{1}$ Doctor in Nursing, Nursing School, Universidade de São Paulo, São Paulo, SP, Brazil. ${ }^{2}$ Master in Nursing at the Universidade Federal de Santa Maria, Santa Maria, RS, Brazil. ${ }^{3}$ Nurse graduated at the Nursing School, Universidade de São Paulo, São Paulo, SP, Brazil. ${ }^{4}$ Associate Professor, Nursing Department, Universidade Federal de Santa Maria, Santa Maria, RS, Brazil. ${ }^{5}$ Doctor Professor, Medical-Surgery Nursing Department, Nursing School, Universidade de São Paulo, São Paulo, SP, Brazil. anascosta@usp.br
} 


\section{INTRODUCTION}

Nursing students face different stressful factors along the university life, including those which stimulate the development and professional maturing ${ }^{(1)}$ and those which threaten the well-being ${ }^{(2)}$, health and quality of life $^{(3)}$.

Thus, in the literature different relative situations to academic, clinical, interpersonal, financial and personal scopes are identified as stressors ${ }^{(4-10)}$. In the academic scope, stressors are pointed as exams, overload of academic work, the delivery of reports and the excess of responsibility ${ }^{(4-6)}$. In the clinical aspect, the fear for unknown situations, the use of medical terms, the diagnosis and treatment of patients, the care offer, the possibility of mistakes in assistance, the management of equipment and the lack of knowledge and professional abilities are highlighted ${ }^{(4-7)}$. In the interpersonal aspect, the relationship with friends, professors and health professionals are punctuated ${ }^{(4-5)}$. In the personal scope, there is the difficulty to control emotions, the low self-esteem, the difficulty to manage time and the fear to give opinions ${ }^{(7-9)}$. In the financial scope, the lack of economic resources is a stressor factor identified by different researchers ${ }^{(7,10)}$.

Added to that, it is noteworthy the socio-demographic characteristics from those students, as gender, age, relationship status, presence of children and ways of transportation, are factors which can lead to the occurrence of stress ${ }^{(11)}$.

Therefore, distinct research showed that nursing students present high levels of stress ${ }^{(12-17)}$. In result of this phenomenon, it is possible the occurrence of physical and psychological manifestations ${ }^{(18-19)}$, within those, headache, depression and anxiety can compromise the academic performance ${ }^{(20)}$ and the relationship with friends and family members ${ }^{(4,20)}$. Thus, it is expected an impact in the quality of life ${ }^{(21)}$ and in the sleep quality ${ }^{(22)}$ of nursing students.

About sleep, in a cross-sectional study with 364 Italian nursing students, it was observed a frequent alteration in the sleep pattern, being insomnia prevalent in $26.7 \%$ of students and occurring increase of this alteration as their age advanced ${ }^{(23)}$. Moreover, the imposed demand from university activities favors the increase of occurrence of sleep quality alterations ${ }^{(23-24)}$. About that, a descriptive exploratory study done with students from the first year of nursing found that after the beginning of classes, there was a predominance of bad sleep quality and daytime indisposition ${ }^{(24)}$. Besides, in a longitudinal study conducted in Sweden that analyzed the sleeping pattern of students in transition between the last year of nursing and the three first years of their insertion in the professional activity, it was observed a bad quality of sleep starting at the last semester of graduation and continued during all analyzed years during their work lives ${ }^{(22)}$. Thus, there is evidence of bad sleep quality also happening in the transition phase between the nursing academic and professional life.
About the relationship between stress and sleep, a research with nursing students from Taiwan, it was verified a significant correlation between stress in clinical practice and sleep quality ${ }^{(25)}$. Still, the sleep duration from students were in average 5 hours per day, with a report of bad sleep quality by $80.9 \%$ of participants ${ }^{(25)}$.

However, in a broad search in the literature, it was verified lack of studies that associate stress factors in nursing academic scenario with sleep quality. Those factors are essential to understand the impact of the academic life in the sleep quality. Those factors are essential to comprehend the academic life impact in the sleep quality of nursing students, considering their peculiarities as individuals in academic training. Based on that knowledge, it will be possible to reorganize the education dynamics and to propose interventions aimed to modify the context experienced by the nursing student with focus on the most stressful factors.

With base on the exposed, we analyzed the influence of stress factors and socio-demographic characteristics in the sleep quality from nursing students.

In this context, we defend the hypothesis that students who experience higher stress present worsening in sleep quality and that some socio-demographic variables characteristic from this sample influenced the decrease in sleep quality.

\section{METHOD}

This was an analytical cross-sectional study with a quantitative approach, conducted during March to April of 2012 in the Nursing School from the Universidade de São Paulo. All students enrolled in the nursing bachelor program, excluding those who were doing exchange programs in other countries and those under 18 years old.

To define the sample size, the proportion criteria was used, considering the relationship between the number of students in each semester and the total of students enrolled in the current year, being the arbitrary coefficient for a risk of $\alpha \leq 0.05$ and risk of $\beta \leq 0.20$ and above 0.9 as prediction power. Therefore, 151 students composed the study sample, as follows: 40 from the first year, 37 from the second year, 36 from the third year and 38 from the fourth year.

In attendance to the Resolution 466/08/2011, the project was approved by the Ethics in Research Committee from the Nursing School of the University of São Paulo, under the protocol no 1100/2011/CEP-EEUSP - SISNEP CAAE: 0101.0.196.000-11. Thus, the students were approached during the class intervals and invited to participate in the research, being informed about the study objectives and with guarantee of secrecy regarding their answers. This way, their consent was registered by the signature of the Free and Informed Consent Term and, after that, the data collection was initiated. 
The data collection instruments were: a form with socio-demographic characteristics, an instrument to Assess Stress of Nursing Students (AEEE) and the Pittsburgh Sleep Quality Index (PSQI).

The socio-demographic form was built to characterize the study sample. Therefore, it involved the following information: gender, age, school semester, relationship status, presence of kid(s), financial support (scholarship), time to travel home-university and home-internships, participation in study groups, with who do they live, work activities, ways of transportation used and weekly time dedicated to studies.

The instrument to Assess the Stress in Nursing Students (AEEE), built and validated to the Brazilian reality in 2009 , allows to evaluate the intensity of stressing factors in nursing students ${ }^{(26)}$. It is composed by 30 items in a Likert Scale, distributed in six domains: Realization of Practical Activities (RAP), referred to activities involving instrumental knowledge to perform procedures and feelings related to the care of patients; Environment (AMB), which involves the level of difficulty to access the internship locations or university, as well as the ways of transportation; Professional Communication (CP), that reflects the difficulty related to communication, professional socializing and conflicting situations; Time Management (GT), which involve the difficulties to conciliate academic activities with personal responsibilities; Professional Training (FP), which contemplates worrying with the acquired knowledge and its impact on the professional development; and Theoretical Activity (AT), which incorporates the level of difficulty in relation to the programmatic content in disciplines and adopted methodology. The original instrument had its internal consistency evaluated by the Cronbach's Alpha varying from 0.71 to $0.87^{(26)}$. In the current research, the Cronbach's Alpha from domains varied from 0.68 to 0.81 and for the 30 items in the scale, it was 0.88 .

The Pittsburgh Sleep Quality Index (PSQI) evaluate the sleep quality in individuals of different samples and it was validated in Brazil by Bertolazi ${ }^{(27)}$. This instrument is composed by 10 questions, distributed in seven components, as follows: Sleep duration, Subject sleep quality, Sleep latency, Habitual sleep efficiency, Sleep disorders, Use of medication to sleep, and Daytime somnolence and disorders. The instrument total scoring varies from 0 to 21 points, and as higher the scoring, the lowest the sleep quality. Scoring higher than five points indicate low sleep quality. In the Brazilian version validation, the instrument presented an Alpha of $0.82^{(27)}$. In the current research, the Cronbach's Alpha was 0.65.

Data was organized and stored in an electronic spreadsheet in the Excel 2007 program for Windows XP. The statistical analysis was conducted on the R statistical program, version 3.0.0. The qualitative variables were presented in absolute and relative values. The quantitative variables were exposed in descriptive measures: mean and standard deviation. Internal consistency analysis of the instrument was calculated by the Cronbach's Alpha. To evaluate the relationship between stress and quality of sleep, a Person's correlation test was calculated. For the analysis of the socio-demographic variables influence on the sleep quality, a linear multiple regression was conducted. Values of $p<0.05$ were considered statistically significant, with a confidence interval of $95 \%$.

\section{RESULTS}

From the 151 students participating in the study, there was a female predominance (94.7\%), with an average age of 20.93 years $(S D=2.71$ ) living with their families $(79.5 \%)$. The students spend an average of 63 minutes (DP $=32.29$ ) to go house-school. As ways of transportation, $80.8 \%$ used buses and $73.5 \%$ the subway to go to the University. Also, it is observed that students dedicate an average of 2.14 hours (DP $=1.58$ ) for studying and $13.3 \%$ mentioned to do extracurricular internships.

Table 1 shows the domains represented with higher frequency a higher level of stress in the students are: Professional Training (30.5\%) and Time Management (27.8\%). Still, Professional Communication represents high level of stress for $25.2 \%$ of students.

Table 1 - Distribution of stress levels in accordance with stress factors from AEEE among nursing students - São Paulo, SP, 2012

\begin{tabular}{|c|c|c|c|c|c|c|c|c|}
\hline \multirow[b]{3}{*}{ AEEE Domains } & \multicolumn{8}{|c|}{ Stress Level } \\
\hline & \multicolumn{2}{|c|}{ Low } & \multicolumn{2}{|c|}{ Medium } & \multicolumn{2}{|c|}{ High } & \multicolumn{2}{|c|}{ Really High } \\
\hline & $\mathrm{N}$ & $\%$ & $\mathrm{~N}$ & $\%$ & $\mathrm{~N}$ & $\%$ & $\mathrm{~N}$ & $\%$ \\
\hline $\begin{array}{l}\text { To perform practical } \\
\text { activities }\end{array}$ & 50 & 33.1 & 53 & 35.1 & 28 & 18.5 & 20 & 13.2 \\
\hline Environment & 76 & 50.3 & 26 & 17.2 & 33 & 21.9 & 16 & 10.6 \\
\hline $\begin{array}{l}\text { Professional Com- } \\
\text { munication }\end{array}$ & 74 & 49.0 & 36 & 23.8 & 38 & 25.2 & 3 & 2.0 \\
\hline Time Management & 56 & 37.1 & 37 & 24.5 & 16 & 10.6 & 42 & 27.8 \\
\hline Professional Training & 58 & 38.4 & 14 & 9.3 & 33 & 21.9 & 46 & 30.5 \\
\hline Theoretical Activity & 69 & 45.7 & 43 & 28.5 & 26 & 17.2 & 13 & 8.6 \\
\hline
\end{tabular}

In Table 2, it is observed that students sleep an average of 6.07 hours (SD = 1.09), $92.7 \%$ do not need medication to sleep and $84 \%$ mentioned to have a sleep efficiency higher than $85 \%$. On the other hand, 50.3\% evaluate a subject sleep quality as bad. Still, there was a predominance of bad sleep quality (78.8\%).

Table 2 - Distribution of nursing students in accordance with sleep quality and sleep components - São Paulo, 2012

\begin{tabular}{llcr}
\hline Variables (n=151) & & $\mathbf{N}$ & $\mathbf{\%}$ \\
\hline \multirow{3}{*}{ Sleep duration } & More than 7 hours & 14 & 9.3 \\
Mean (SD)=6.07 (1.09) & $\mathbf{6 - 7}$ hours & $\mathbf{9 3}$ & $\mathbf{6 1 . 6}$ \\
& $5-6$ hours & 30 & 19.9 \\
& Less than 5 hours & 14 & 9.3 \\
\hline \multirow{3}{*}{ Sleep Latency } & $\leq 15$ min. & 40 & 26.5 \\
& $\mathbf{1 6 - 3 0 ~ m i n .}$ & $\mathbf{6 6}$ & $\mathbf{4 3 . 7}$ \\
& $31-60$ min. & 36 & 23.8 \\
& $>60$ min. & 9 & 6.0 \\
\hline
\end{tabular}


Continuation

\begin{tabular}{|c|c|c|c|}
\hline Variables $(n=151)$ & & $\mathbf{N}$ & $\%$ \\
\hline \multirow{4}{*}{ Habitual Sleep Efficiency } & $>85 \%$ & 127 & 84.1 \\
\hline & $75-84 \%$ & 19 & 12.6 \\
\hline & $65-74 \%$ & 4 & 2.6 \\
\hline & $<65 \%$ & 1 & 0.7 \\
\hline \multirow{4}{*}{ Sleep Disorders } & None & 2 & 1.3 \\
\hline & Less than 1 time/wk. & 114 & 75.5 \\
\hline & 1 to 2 times/wk. & 35 & 23.2 \\
\hline & 3 times/or more & 0 & 0.0 \\
\hline \multirow{4}{*}{ Subjective Sleep Quality } & Very good & 14 & 9.3 \\
\hline & Good & 55 & 36.4 \\
\hline & Bad & 76 & 50.3 \\
\hline & Very Bad & 6 & 4.0 \\
\hline \multirow{4}{*}{ Daytime Dysfunction } & None & 11 & 7.3 \\
\hline & Less than 1 time/wk & 73 & 48.3 \\
\hline & 1to 2 times/wk. & 45 & 29.8 \\
\hline & 3 times/wk or more & 22 & 14.6 \\
\hline \multirow{4}{*}{ Use of medication to sleep } & None & 140 & 92.7 \\
\hline & Less than 1 time/wk & 5 & 3.3 \\
\hline & 1 to 2 times/wk & 6 & 4.0 \\
\hline & 3 times/wk or more & 0 & 0.0 \\
\hline \multirow{2}{*}{$\begin{array}{l}\text { Score of sleep quality } \\
\text { Mean }(S D)=7.28(2.26)\end{array}$} & Good ( $\leq 5$ points $)$ & 32 & 21.19 \\
\hline & Bad ( $>5$ points) & 119 & 78.81 \\
\hline
\end{tabular}

Note: Absolute $(\mathrm{N})$ and relative (\%) frequency.

In Table 3, it is observed a positive correlation of the quality of sleep with the domain Professional Communication (PC) $(r=0.21, p<0.01)$, Professional Training (PT) $(r=0.21, p<0.01)$, and Theoretical Activity (TA) $(r=0.23$, $\mathrm{p}<0.01)$, that is, as higher the academic stress, less is the sleep quality. Other domains (PAR - Practical Activities Realization; ENV - Environment; and TM - Time Management) did not present significant correlation with PSQI.

Table 3 - Correlation between sleep quality and stress factors of AEEE between nursing students - São Paulo, 2012

\begin{tabular}{llllllll}
\hline & PSQI & PAR & ENV & PC & TM & PT & TA \\
\hline PSQI & 1 & & & & & & \\
PAR & 0.13 & 1 & & & & & \\
ENV & 0.06 & $0.69^{* * *}$ & $0.18^{*}$ & & & & \\
PC & $0.21^{* *}$ & $0.16^{*}$ & $0.26^{* * *}$ & 1 & & & \\
TM & 0.09 & $0.23^{*}$ & $0.65^{* * *}$ & $0.29^{* * *}$ & 1 & & \\
PT & $0.21^{* *}$ & $0.73^{* * *}$ & $0.18^{*}$ & $0.26^{* * *}$ & 0.15 & 1 & \\
TA & $0.23^{* *}$ & $0.23^{* *}$ & $0.18^{*}$ & $0.43^{* * *}$ & $0.2^{* *}$ & $0.32^{* * *}$ & 1 \\
\hline
\end{tabular}

Pearson's Correlation; *** $\mathrm{p}<0.0001 ;{ }^{* *} \mathrm{p}<0.01 ;{ }^{*} \mathrm{p}<0.05$.

When analyzing the data with a multiple linear regression model, with $R^{2}=0.4527$ and adjusted $R^{2}=0.3674$ with $p<0.0001$ (Table 4), the variables diminishing the sleep quality are: to perceive the domain Professional Training as a stressor $(\beta=0.27 ; p=0.00)$, to be enrolled in the first academic year $(\beta=2.75 ; p=0.00)$, to work $(\beta=1.86 ; p=0.01)$ and to dedicate more hours for studying $(\beta=0.67 ; p=0.01)$.
Table 4 - Influence of stress factors and socio-demographic variables in the sleep quality of nursing students (Multiple Linear Regression) - São Paulo, 2012

\begin{tabular}{|c|c|c|c|c|}
\hline & $\beta$ & EP** & t-Value & p-Value \\
\hline (Intercept) & 2.97 & 2.66 & 1.12 & 0.27 \\
\hline Age (years) & -0.13 & 0.08 & -1.65 & 0.10 \\
\hline \multicolumn{5}{|l|}{ Relationship Status } \\
\hline Married & Reference & & & \\
\hline Single & 0.48 & 1.15 & 0.42 & 0.68 \\
\hline Stable relationship & -3.26 & 1.77 & -1.84 & 0.07 \\
\hline \multicolumn{5}{|l|}{ Academic year } \\
\hline Second & Reference & & & \\
\hline First & 2.75 & 0.78 & 3.51 & $0.00 *$ \\
\hline Third & 0.15 & 0.63 & 0.23 & 0.82 \\
\hline Fourth & -0.02 & 0.65 & -0.04 & 0.97 \\
\hline \multicolumn{5}{|l|}{ Stress domains } \\
\hline $\begin{array}{l}\text { Domain } 5 \text { - Professional } \\
\text { Training }\end{array}$ & 0.27 & 0.08 & 3.37 & $0.00 *$ \\
\hline \multicolumn{5}{|l|}{ Types of transportation } \\
\hline \multicolumn{5}{|l|}{ Bus } \\
\hline No & Reference & & & \\
\hline Yes & 1.03 & 0.56 & 1.85 & 0.07 \\
\hline \multicolumn{5}{|l|}{ Mobility } \\
\hline $\begin{array}{l}\text { Home-Internship location } \\
\text { (minutes) }\end{array}$ & 0.00 & 0.01 & 0.08 & 0.93 \\
\hline \multicolumn{5}{|l|}{ Work } \\
\hline No & Reference & & & \\
\hline Yes & 1.86 & 0.67 & 2.75 & $0.01 *$ \\
\hline \multicolumn{5}{|l|}{ Research Group } \\
\hline Do not participate & Reference & & & \\
\hline Participate & 0.91 & 0.49 & 1.87 & 0.06 \\
\hline Study time (h/week) & 0.67 & 0.25 & 2.69 & $0.01 *$ \\
\hline
\end{tabular}

*Statistically significant value $(p<0.05)$.

** SE= Standard Error.

\section{DISCUSSION}

In the present research, Professional Training and Time Management represented with higher frequency, a very high level of stress for nursing students, as well as Professional Communication represented high level of stress for those individuals.

Professional Training, understood as the preoccupation with the acquired knowledge at this phase of academic training and its impact in professional life is also perceived as stressing for nursing students of different socio-cultural contexts. An investigation with 373 nursing students from Egypt found fear of the professional future as a stressor for $82.6 \%$ of students and the academic load for $59.8 \%$ of the sample ${ }^{(18)}$. Another investigation conducted between 130 nursing students from Rio Grande do Sul identified Professional Training representing high level of stress for $20 \%$ of students and medium level for $40.77 \%$ of that population ${ }^{(11)}$.

Regarding time management, students have difficulties to conciliate curriculum activities with other personal, emotional and social demands. This way, when starting 
superior education, students experience the intensification of academic requirements, different opportunities in research and teaching, the need to work to their own maintenance and, many times, the mobility to the university campus. In this context, students need to manage the distinct daily demands and to conciliate those with family and social conviviality, which contributes to the elevation of stress level of students. In a research conducted with 100 nursing students from Saudi Arabia, the excess of academic responsibilities was the most frequent stressor factor within those individuals $s^{(5)}$. In another study, involving students from the $4^{\text {th }}$ year of nursing bachelor's in Campinas, to conciliate work and studies (63.6\%) and difficulty to conciliate study and leisure (40.9) were considered the most stressful activities ${ }^{(27)}$.

In addition, communication and relationship with peers and health professionals represent a high level of stress among students. Considering nursing students being in general young, it is possible for them to present less experience dealing directly with people and more difficulty to deal with assistance questions with the health team. Besides that, it is possible that competition in the search for knowledge and personal differences among peers from the course to cause conflicts in the assistencial environment. Thus, a research with 343 nursing students in Egypt found conflicting relationships among course colleagues was one of most frequent stressors ${ }^{(18)}$. An investigation conducted with 366 nursing students in Iran, conflicts with colleagues was observed $(52.2 \%)$, relationship problems with parents $(20.2 \%)$ and partners $(31.1 \%)$ and experiences with new situations and non-familiar (64.2\%) were considered the stressors most punctuated by subjects ${ }^{(20)}$.

Considering this context, the occurrence of stress in nursing students is possible when inserted in academic environment and the influence of this phenomenon in the sleep quality of students. Thus, $78.8 \%$ of students presented low sleep quality and the stress level interferes in the sleep quality $(p=0.016)$, in a certain way that as higher the stress level, less is the sleep quality. About that, it should be highlighted that many times, the student use part of their sleep period to attend academic (study and readings) and social demands (meetings with friends and family events). As consequence, the student sleep later and wake up early to get to the academic location, which implicates in less sleeping time during the night, generally below the necessary for the organic reestablishment. About that, a research with 234 nursing student in Peru identified $62 \%$ of students presented changes in sleeping habits after starting the course $\mathrm{e}^{(14)}$.

In the present research, a positive correlation was found between the stress factors Professional Communication, Professional Training and Theoretical Activity and sleep quality. Still, in the linear regression (Table 4), it was attested that Professional Training positively impacted sleep quality. About that, the present conflicts in relationships with colleagues and health professionals are high- lighted. Their preoccupation with acquisition of knowledge, their insertion in the work market as well as the difficulties related to learned contents and methodologies exceed their cognitive resources. As consequence, many times, the student takes longer to fall sleep, sleep for a shorter total time or cannot sleep during the night, which diminishes the sleep quality. In a research with 44 university students in Brazil, the reduction in sleeping time was associated with the increase of subjects with points indicating bad sleep quality and moderate or severe indisposition for daily activities development. Still, the start time of academic activities contributed to anticipate the wake up time, which seemed to aggravate the bad sleep quality ${ }^{(24)}$.

Besides the stress factors presented, it is important to consider that few socio-demographic characteristics can influence the sleep quality. Thus, to be enrolled in the first academic year, to perform work activities and to spend more time studying contributes to the reduction on the sleep quality. The fact of being enrolled in the first year implicates a considerable volume in theoretical subjects and in the need to adapt to a new environment, with requirements and activity load higher than high school ${ }^{(26)}$. It requires more daily studying time, substituting part of the sleeping time for this task, reflecting on sleep quality, a verified fact in $50.3 \%$ of students with bad subjective sleep quality. About that, a research conducted with 44 university students in São Paulo identified that after the start of classes, there was a higher number of students with bad sleep quality and daily indisposition when compared to vacation period ${ }^{(24)}$. The authors believe that it happens due to the subjection of students of rigid timetables adopted to start academic activities or the adoption of irregular sleeping habits incorporated by students during school period ${ }^{(24)}$.

Still, to perform work activities together with the bachelor degree course requires the student to attend beyond academic demands, the work time requirements, which can lead to an over load and affect the sleep quality and duration. About this fact, an investigation with 30 nursing students in São Paulo who worked during night shifts, it was verified the presence of excessive daily somnolence ${ }^{(28)}$. The authors concluded that night worker, who suffer sleep deprivation, have additional time in vigil due to studies. It causes higher levels of somnolence, which can damage their academic and work performance ${ }^{(28)}$.

\section{CONCLUSION}

Time Management and Professional Training represented very high level of stress for nursing students and Professional Communication represented high level of stress for them. Students presented bad sleep quality and there was significant positive correlation between the level of stress and sleep quality, and Professional Training contributed to bad sleep quality. Adding to that, time spent in studying, having a job and being enrolled in the first course semester were negative influencing aspects in sleep quality.
Influence of stress factors and socio-demographic characteristics on the sleep quality of nursing students Benavente SBT, Silva RM, Higashi AB, Guido LA, Costa ALS 
Thus, academic environment factors and some sociodemographic characteristics interfere on the nursing student routine, contributing to the sleep quality reduction, which confirms the hypothesis of the present study. Thereafter, there is possible impact in learning and the quality of nursing care when there is their insertion in the clinical care environment.

\section{REFERENCES}

1. Gibbons C, Dempster M, Moutray M. Stress and eustress in nursing students. J Adv Nurs. 2007;61(3):282-90.

2. Gibbons C, Dempster M, Moutray M. Stress, coping and satisfaction in nursing students. J Adv Nurs. 2011;67(3):621-32.

3. Moreira DP, Furegato ARF. Stress and depression among students of the last semester in two nursing courses. Rev Latino Am Enferm [Internet]. 2013[cited 2013 Nov 10]; 21(n. spe):155-62. Available from: http://www.scielo.br/pdf/rlae/ v21nspe/pt_20.pdf

4. Yamashita K, Saito M, Takao T. Stress and coping styles in Japanese nursing students. Int J Nurs Pract. 2012;18(5):489-96.

5. Eswi AS, Radi S, Youssri H. Stress/stressors as perceived by baccalaureate Saudi nursing students. Middle East J Sci Res. 2013;14(2):193-202.

6. Chan CKL, So WKW, Fong DYT. Hong Kong baccalaureate nursing students' stress and their coping strategies in clinical practice. J Prof Nurs. 2009;25(5):307-13.

7. Bowden J. Why do nursing students who consider leaving stay on their courses? Nurse Res. 2008;15(3):45-58.

8. Pacheco S. Stress e mecanismos de coping nos estudantes de enfermagem. Referência Rev Enferm. 2008;2(7):89-95.

9. Altiok HO, Üstün B. The stress sources of nursing students. Educ Sci Theory Pract [Internet]. 2013;13(2):760-6. Available from: http://www.edam.com.tr/kuyeb/pdf/en/646273c229b b2a936c877a2470ca8e4aokeng.pdf

10. Timmins F, Kaliszer M. Aspects of nurse education programmes that frequently cause stress to nursing students: fact-finding sample survey. Nurse Educ Today. 2002; 22(3):203-11

11. Freitas EO. Estresse, coping, burnout: sintomas depressivos e hardiness entre discentes de Enfermagem [dissertação]. Santa Maria: Universidade Federal de Santa Maria; 2012.

12. Reeve KL, Shumaker CJ, Yearwood EL, Crowell NA, Riley JB. Perceived stress and social support in undergraduate nursing student's educational experiences. Nurse Educ Today. 2013;33(4):419-24.
In this perspective, the reorganization of the teaching dynamics and the proposal of actions focused in high stress factors and in those contributing to bad sleep quality to assist students in their academic activities development.

The present investigation presented a panorama which allows to re think the nursing training aimed to minimize stress and to improve sleep quality in students.

13. Huaquín Mora VR, Loaíza Herrera R. Exigencias académicas y estrés en las carreras de la Facultad de Medicina de la Universidad Austral de Chile. Estud Pedagog. 2004; (30):39-59.

14. Ticona Benavente SB, Paucar Quispe G, Llerena Callata G. Nivel de estrés y estratégias de afrontamiento en estudiantes de la facultad de Enfermería-UNSA Arequipa. 2006. Enferm Glob [Internet]. 2010 [citado 2013 nov. 10];(19):1-18. Disponible en: http://scielo.isciii.es/pdf/eg/n19/docencia1.pdf

15. Watson R, Deary I, Thompson D, Li G. A study of stress and burnout in nursing students in Hong Kong: a questionnaire survey. Int J Nurs Stud. 2008;45(10):1534-42.

16. Edwards D, Burnard P, Bennett K, Hebden U. A longitudinal study of stress and self-esteem in student nurses. Nurse Educ Today. 2010;30(1):78-84.

17. Maville JA, Kranz PL, Tucker BA. Perceived stress reported by nurse practitioner students. J Am Acad Nurse Pract. 2004;16 (6):257-62

18. Amr A, El-Gilany AH, El-Moafee H, Salama L, Jimenez C. Stress among Mansoura (Egypt) baccalaureate nursing students. Pan Afr Med J [Internet]. 2011[cited 2013 Nov 12];8:26. Available from: http://www.ncbi.nlm.nih.gov/ pmc/articles/PMC3201591/pdf/pamj-8-26.pdf

19. Benavente SBT, Costa ALS. Respostas fisiológicas e emocionais ao estresse em estudantes de enfermagem: revisão integrativa da literatura. Acta Paul Enferm [Internet]. 2011[cited 2013 Nov 12];24(4):571-6. Available from: http://www. scielo.br/pdf/ape/v24n4/a19v24n4.pdf

20. Seyedfatemi N, Tafreshi M, Hagani H. Experienced stressors and coping strategies among Iranian nursing students. BMC Nurs [Internet]. 2007 [cited 2013 Nov 17];6:11. Available from: http://www.biomedcentral.com/content/pdf/14726955-6-11.pdf

21. Yeoungsuk S. Stressful life events and quality of life in nursing students. J Korean Acad Soc Nurs Edu. 2012;18(1):71-80.

22. Hasson D, Gustavsson P. Declining sleep quality among nurses: a population-based four-year longitudinal study on the transition from nursing education to working life. PLoS One. 2010;5(12):e14265. 
23. Angelone AM, Mattei A, Sbarbati M, Di Orio F. Prevalence and correlates for self-reported sleep problems among nursing students. J Prev Med Hyg. 2011;52(4):201-8.

24. Furlani R, Ceolim MF. Padrões de sono de estudantes ingressantes na Graduação em Enfermagem. Rev Bras Enferm [Internet]. 2005 [citado 2013 out. 23];58(3):320-4. Disponível em: http://www.scielo.br/pdf/reben/v58n3/a13v58n3.pdf

25. Huang YW, Yang CH, Ho SL, Hwu YJ. The relationship between practicum-related stress and sleep quality in nursing students. J Nurs Health Res. 2011;7(1):14-25.

26. Costa ALS, Polak C. Construction and validation of an instrument for the assessmentof stress among nursing students (AEEE). Rev Esc Enferm USP [Internet]. 2009 [cited 23 Oct 2012];43(n.spe):1017-26. Available from: http://www.scielo.br/pdf/reeusp/v43nspe/en_a05v43ns.pdf
27. Bertolazi AN. Tradução, adaptação cultural e validação de dois instrumentos de avaliação do sono: escala de sonolência de Epworth e índice de qualidade de sono de Pittsburgh [dissertação]. Porto Alegre: Faculdade de Medicina, Universidade Federal do Rio Grande do Sul; 2008.

28. Ferreira LRC, De Martino MMF. Sleep patterns and fatigue of nursing students who work. Rev Esc Enferm USP [Internet]. 2012[cited 2013 Oct 24];46(5):1178-83. Available from: http://www.scielo.br/pdf/reeusp/v46n5/en_20.pdf 